\title{
DAMPAK KELEMBAGAAN BAGI HASIL TERHADAP KINERJA USAHA PENGGEMUKAN SAPI POTONG DI KABUPATEN KUPANG
}

\author{
Obed Haba Nono \\ Staf Pengajar Fakultas Peternakan Universitas Nusa Cendana Kupang - NTT \\ JIn. Suratim 48 Oesapa Kupang -NTT Telp : 0380 - 881874. \\ E-mail : obedhaba@gmail.com
}

\begin{abstract}
ABSTRAK. Tujuan penelitian ini adalah untuk mengetahui dampak keberadaan kelembagaan bagi hasil terhadap kinerja usaha penggemukan sapi potong. Penelitian survai dilaksanakan di Kabupaten Kupang Provinsi Nusa Tenggara Timur Metode penentuan wilayah/responden yang digunakan multi stage cluster random sampling, diperoleh 2 kecamatan contoh dan 6 desa contoh, dan total responden sebanyak 107 orang, terdiri dari 72 peternak bagi hasil (penggaduh) dan 35 peternak mandiri. Untuk Pemodal dilakukan sensus sehingga diperoleh 23 pemodal. Hasil penelitian menunjukkan bahwa: kinerja usaha (penerimaan, pendapatan, keuntungan dan ROI) peternak mandiri lebih baik daripada kinerja usaha penggaduh. Kelembagaan bagi hasil belum meningkatkan produktivitas usaha. Nilai ROI sebesar 16,69 s/d 32,23 persen. Jadi, pemanfaatan aset usaha tani belum optimal. Efsiensi usaha R/C sebesar 1,97 (belum memperhitungkan biaya pakan dan tenaga kerja keluarga). Pertambahan bobot harian ternak penggemukan berkisar antara 378,41 s/d 410,88 gram. Kelembagaan bagi hasil belum meningkatkan produktiivtas usaha.
\end{abstract}

Kata kunci : bagi hasil, penggaduh, penggemukan, sapi potong

\section{THE IMPACT OF SHARING ARRANGEMENTS SYSTEM TO THE BEEF CATTLE FATTENING FARM PERFORMANCE IN KUPANG DISTRICT}

\begin{abstract}
This research aims to know the impact of sharing arrangements system to the beefcattle fattening farm performance. The survey methods of research was conducted in Kupang District - East Nusa Tenggara Province. Sample area of the research sorted out through multi-stage cluster random sampling technique. Research consisted of 2 sub-district, and 6 villages. Total respondents were 107 farmers consisted of 72 farmers who were participant (FP) of Sharing Arrangements Institution (SAI) and 35 farmers who were non-participant (FnP). Meanwhile, investor amounted to 23 both individual and institutions sorted out through census technique. The result of the performance indicators of fattening farm such as revenue, net profit and return on investment can be explained that the performance of $\mathrm{FnP}$ was higher than FP. ROI were from 16.69 till 32.23 percent. Farm efficiency $(R / C)=1,97$ (which is accounted by wages of family
\end{abstract}


labour or feed cost not accounted yet). Average daily gain (ADG) were from 378,41 till 410,88 grams. The SAI not increase farm productivity yet.

Keywords: sharing arrangements systems, participant farmers, fattening, beef cattle

\section{PENDAHULUAN}

Konsepsi dan anatomi kelembagaan di perdesaan, merupakan wujud dari keterkaitan antar empat faktor, yaitu dukungan sumber daya (resource endowments), dukungan budaya (cultural endowments), teknologi (technology) dan kelembagaan (institution) (Hayami dan Ruttan (1984). Oleh karena itu, sumber daya alam, sumber daya manusia, teknologi dan kelembagaan merupakan empat faktor penggerak pembangunan pertanian (Pakpahan, 1989). Keempat faktor tersebut saling menunjang. Oleh karena itu, penerapan teknologi saja tidak cukup untuk mengatasi permasalahan di tingkat usahatani tapi perlu diimbangi dengan pengelolaan sumber daya alam, manusia dan kelembagaannya. Jadi, aspek kelembagaan merupakan salah satu faktor yang harus diperhitungkan dalam kerangka pembangunan termasuk dalam analisis ekonomi. Kelembagaan yang mengatur penggunaan teknologi dalam produksi sehingga memungkinkan masyarakat maupun anggotanya memanfaatkan peluang produksi dan pasar sebaik-baiknya.

Dari sudut kelembagaan ekonomi peternakan sapi potong, di wilayah penelitian terdapat sejumlah sistem bagi hasil. Hal ini berkatan erat dengan karakteristik wilayah, karakteristik komoditi, aturan main serta pelaksanaan unsurunsur kelembagaan dari setiap bentuk kelembagaan (sistem bagi hasil), tipe pemodal, faktor-faktor pendorong setiap pelaku untuk melakukan kerjasama, komitmen setiap pelaku untuk menjalankan kesepakatan atau kerjasama dalam kelembagaan tersebut akan berpengaruh kepada : distribusi share, kinerja usaha bagi hasil tersebut seterusnya berpengaruh terhadap keberlanjutan kelembagaan tersebut. Jadi, keberadaan kelembagaan bagi hasil tentu berpengaruh terhadap sistem produksi usaha ternak (termasuk penggemukan sapi). Artinya, kelembagaan bagi hasil berpengaruh terhadap keberlangsungan produksi yang bermuara pendapatan rumah tangga peternak yang ikut di dalamnya dan akhirnya berdampak kepada profil ekonomi wilayah.

Berdasarkan uraian di atas, maka permasalahan dalam penelitian ini adalah sejauh mana keberadaan sistem bagi hasil sebagai suatu bentuk kelembagaan ekonomi memberikan pengaruh kepada kinerja usaha penggemukan sapi potong dan perekonomian wilayah/sentra produksi komoditi tersebut. Jadi, permasalahan yang dirumuskan adalah sejauh mana perbedaan kinerja usaha penggemukan sapi potong antara penggaduh dengan usaha peternak mandiri. Tujuan penelitian adalah menguraikan variasi kinerja usaha penggemukan sapi potong dari peternak penggaduh sesuai dengan jenis pemodal dengan peternak mandiri. 


\section{METODE PENELITIAN}

Penelitian ini difokuskan kepada pelaksanaan sistem bagi hasil dalam aspek produksi dalam kaitan pengaruhnya terhadap kinerja usaha penggemukan sapi potong. Lokasi penelitian adalah Kabupaten Kupang - Propinsi Nusa Tenggara Timur sebagai sentra produksi dan keberadaan kelembagaan bagi hasil terbesar dibandingkan dengan 19 kabupaten lainnya di Nusa Tenggara Timur. Penentuan lokasi/responden dengan teknik multistage cluster random sampling, yaitu penentuan mulai kabupaten (Kabupaten Kupang), dan tingkat kecamatan (terdapat dua kecamatan, yaitu Amarasi dan Fatuleu) serta tingkat desa (masingmasing untuk kecamatan Amarasi meliputi tiga desa dan Fatuleu juga tiga desa). Jumlah sampel berdasarkan alokasi proporsional sesuai (Rasyid, 1994) diperoleh sampel penggaduh sebanyak 72 orang, dan peternak mandiri sebanyak 35 orang. Sebagai data pasangan untuk validasi data kinerja dari peternak penggaduh dilakukan croschekck dari pemodalnya. Untuk pemodal, terdiri dari tiga jenis, yaitu pemerintah, swasta luar (pihak swasta yang berdomisili di luar wilayah penelitian) dan swasta lokal (berdomisili di wilayah setempat). Jumlah pemodal sebanyak 23 orang (sebagai individu atau lembaga).

\section{Model Analisis}

\section{Perbandingan Kinerja Antar Jenis Penggaduh dan Usaha Mandiri}

Untuk empat variabel kinerja, yaitu penerimaan, pendapatan, keuntungan, dan tingkat pengembalian modal dari usaha penggaduh dan mandiri menggunakan uji beda dua arah, uji- F, berdasarkan Siagian dan Sugiarto (2002) yaitu uji beda rata-rata lebih dari dua :

$$
\begin{aligned}
& \text { k n k }
\end{aligned}
$$

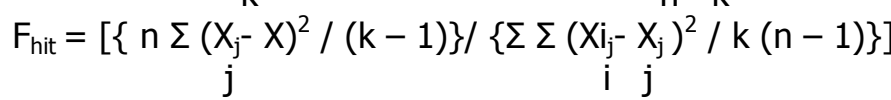

dan dilanjutkan dengan Uji Tukey.

\section{Perbandingan Kinerja Antara Usaha Penggaduh dengan Usaha Mandiri}

Untuk ini digunakan uji beda satu arah, yaitu uji- t, dengan rumus:

$$
\begin{gathered}
t_{\text {hitung: }} \frac{\mu R_{p}-\mu R m}{\sqrt{\left(n_{1}-1\right) S_{1}^{2}+\left(n_{2}-1\right) S_{2}^{2}}} \sqrt{n_{1} n_{2}\left(n_{1+} n_{2}-2\right)} \\
d b=n_{1+} n_{2}-2 \\
\text { Keterangan : } \\
\mu \mathrm{Tp}=\begin{array}{l}
\text { penerimaan, pendapatan, keuntungan dan tingkat } \\
\text { pengembalian modal penggaduh }
\end{array} \\
\mu \mathrm{Tm}=\begin{array}{l}
\text { penerimaan, pendapatan, keuntungan dan tingkat } \\
\text { pengembalian modal mandiri }
\end{array}
\end{gathered}
$$




$$
\begin{aligned}
\mathrm{S}_{1} & =\text { simpangan baku dari } \mu \mathrm{R}_{\mathrm{p}} \\
\mathrm{S}_{2} & =\text { simpangan baku dari } \mu \mathrm{Rm} \\
\mathrm{n}_{1} & =\text { jumlah sampel penggaduh } \\
\mathrm{n}_{2} & =\text { jumlah sampel mandiri }
\end{aligned}
$$

Rumus untuk Return on Investment (ROI) :

\{Penerimaan kotor - (biaya produksi total + pinjaman + bunga modal)/ Total nilai aset usaha tani. X $100 \%$

\section{HASIL DAN PEMBAHASAN}

\section{Gambaran Umum Usaha Penggemukan Sapi Potong}

Adapun jenis ternak sapi potong yang dipelihara adalah ternak sapi bali dan turunannya. Tradisi budidaya usahaternak sapi potong, dengan daya dukung lahan yang masih luas, seperti pemanfaatan kebun/ladang yang ditanami larikan aneka legum, kawasan kehutanan dan padang penggembalaan potensi pengembangan usahaternak sapi potong masih sangat besar. Usaha penggemukan dilakukan secara semi intensif /diikat pindah atau dikandangkan, pakan diberikan secara cut and carry. Bahan pakan terutama legum seperti lamtoro, gamal, aneka tanaman pohon lainnya seperti kabesak, asam, kapuk, beringin dan lain sebagainya. Umumnya lama penggemukan sekitar 8-18 bulan. Produk penggemukan dipasarkan terutama ke wilayah Ibukota (Jabodetabek). Produksi bibit selain untuk kebutuhan NTT juga untuk wilayah lainnya di tanah air.

\section{Kelembagaan Bagi Hasil}

Kelembagaan bagi hasil antar penggaduh dengan pemodal sudah berlangsung sejak lama. Umumnya ada variasi share yang diterima penggaduh (sesuai kesepakatan sebelumnya). Variasi itu dapat berdasarkan kepada : (1) persentase dari nilai hasil penggemukan setelah dikurangi nilai awal atau harga bakalan. Share ini bervariasi dan berkisar antar 60-70 persen; (2) berdasarkan kenaikan bobot badan yang dikonversikan berdasarkan harga pasar lokal.

Operasional kelembagaan bagi hasil untuk tipe penggemukan menyangkut hak, kewajiban, wewenang pelaku tertera dalam Tabel 1.

Untuk hak penggaduh seperti transfer teknologi budidaya meliputi: teknologi pakan, teknologi reproduksi yang ditujukan untuk peningkatan produksi dan produktivitas usaha tidak ada. Hal ini mengindikasikan belum optimalnya aturan main kelembagaan bagi hasil yang ada .

Pada aspek kewenangan penggaduh, sebenarnya masih terdapat kelemahan yaitu meliputi penentuan umur ternak bakalan, penentuan waktu jual, serta penentuan pembeli produk dimana semua ditentukan oleh pihak pemodal. Hal ini menunjukkan bahwa posisi tawar peternak atau peggaduh sangat lemah. Akibatnya ada ketidak pastian lama pemeliharaan yang cenderung menjadi sangat lama dengan rata-rata $>10$ bulan. Oleh karena itu, dalam kerangka pengembangan kelembagaan bagi hasil yang lebih proporsional dibutuhkan penataan lebih lanjut. 
Sosiohumaniora, Volume 13, No.1, Maret 2011 : 28 - 38

Tabel 1. Pelaksanaan Aspek kelembagaan Bagi Hasil Usaha Penggemukan

\begin{tabular}{|c|c|c|c|c|}
\hline No & Keterangan & \multicolumn{3}{|c|}{ Bagi Hasil Peternak/Penggaduh dengan } \\
\hline & & Pemerintah & Swasta Luar & Swasta Lokal \\
\hline \multirow[t]{10}{*}{1} & \multicolumn{4}{|l|}{ Hak Penggaduh } \\
\hline & $\begin{array}{l}\text { Peroleh Modal/ } \\
\text { ternak bakalan }\end{array}$ & Ya & Ya & Ya \\
\hline & Transfer teknologi & Tidak & Tidak & Tidak \\
\hline & Jaminan pasar & $\begin{array}{l}\text { Bebas } \\
\text { menjual }\end{array}$ & $\begin{array}{l}\text { Ya (pemodal ikut dalam penjualan) } \\
\text { atau langsung sebagai pembeli }\end{array}$ & $\begin{array}{l}\text { Ya (pemodal ikut jual atau } \\
\text { beli }\end{array}$ \\
\hline & \multicolumn{4}{|l|}{ Fasilitas tambahan } \\
\hline & Tali & $\begin{array}{l}\text { Ya, awal } \\
\text { gaduhan }\end{array}$ & Ya, pada awal gaduhan & Ya, pada awal gaduhan \\
\hline & Vaksin/obat & tidak & $\begin{array}{l}\text { Ya untuk } 3 \text { bulan pertama, ada yang } \\
\text { tidak }\end{array}$ & $\begin{array}{l}\text { Ya untuk 3bulan prtama, } \\
\text { ada yang tidak }\end{array}$ \\
\hline & Insentif uang tunai & tidak & Bervariasi (ada dan tidak) & Bervariasi (ada \& tidak) \\
\hline & $\begin{array}{l}\text { Kepastian tingkat } \\
\text { harga }\end{array}$ & $\begin{array}{l}\text { Ya, sesuai } \\
\text { pasar }\end{array}$ & Ya, sesuai pasar & Ya, sesuai pasar \\
\hline & $\begin{array}{ll}\text { Nilai } & \text { pertambahan } \\
\text { modal } & \\
\end{array}$ & tidak & Bervariasi (ada ya atau tidak) & tidak \\
\hline 2 & \multicolumn{4}{|c|}{ Kewajiban Penggaduh $*$ ) } \\
\hline \multirow[t]{5}{*}{3} & \multicolumn{4}{|c|}{ Wewenang Penggaduh } \\
\hline & $\begin{array}{l}\text { Menentukan umur } \\
\text { bakalan }\end{array}$ & tidak & tidak & tidak \\
\hline & $\begin{array}{l}\text { Menentukan bobot } \\
\text { minimal bakalan }\end{array}$ & tidak & tidak & tidak \\
\hline & $\begin{array}{l}\text { Menentukan waktu } \\
\text { gulir/jual }\end{array}$ & ya & Ya, tidak & Ya, tidak \\
\hline & $\begin{array}{l}\text { Menentukan pembeli } \\
\text { produk }\end{array}$ & ya & Ya, tidak & Ya, tidak \\
\hline \multirow[t]{11}{*}{4} & \multicolumn{4}{|l|}{ Kontrak Bagi Hasil } \\
\hline & $\begin{array}{l}\text { Bentuk dan isi } \\
\text { kontrak }\end{array}$ & tertulis & Umumnya tidak terlalu detail, & tidak \\
\hline & Penyusunan kontrak & $\begin{array}{l}\text { oleh } \\
\text { pemodal }\end{array}$ & kesepakatan & kesepakatan \\
\hline & \multirow[t]{2}{*}{ Isi kontrak } & \multicolumn{3}{|c|}{$\begin{array}{l}\text { Lingkup pekerjaan, hak dan kewajiban, jangka waktu, pelaksanaan, penjualan,sank- } \\
\text { si,force majeur, pembatalan perjanjian, penyelesaian perselisihan }\end{array}$} \\
\hline & & ya & Hanya Puskud wajib berkelompok, & $\begin{array}{l}\text { Hanya kesepakatan, } \\
\text { pendekatan individual }\end{array}$ \\
\hline & Jangka waktu & $\begin{array}{l}0,5-1,5 \\
\text { tahun } \\
\text { tergantung } \\
\text { pertam- } \\
\text { bahan bobot } \\
\text { badan } \\
\end{array}$ & $\begin{array}{l}\text { Bervariasi } \text { sesuai } \\
\text { kesepakatan lisan, hanya untuk } \\
\text { Puskud penggaduh sesuai syarat } \\
\text { sebagai anggota koperasi }\end{array}$ & $\begin{array}{lr}\text { Bervariasi sesuai } & \text { dengan } \\
\text { kesepakatan } & \text { lisan, } \\
\text { sepanjang penggaduh } \\
\text { masih } \\
\text { melaksanakannya }\end{array}$ \\
\hline & Penentuan harga & bebas & $\begin{array}{l}\text { Bebas, Cuma Puskud yang } \\
\text { berdasarkan berat hidup minimal }\end{array}$ & bebas \\
\hline & $\begin{array}{l}\text { Penentuan standar } \\
\text { produk }\end{array}$ & tidak & $\begin{array}{l}\text { Umumnya tidak, hanya puskud yang } \\
\text { menentukan standar minimal } 250 \mathrm{~kg}\end{array}$ & Tidak sesuai kebutuhan \\
\hline & Penentuan waktu jual & bebas & $\begin{array}{l}\text { Bebas, hanya puskud yg intervensi } \\
\text { harus minimal } 250 \mathrm{~kg}\end{array}$ & $\begin{array}{l}\text { Kesepakatan (sesuai } \\
\text { kebutuhan penggaduh) }\end{array}$ \\
\hline & $\begin{array}{l}\text { Share yang dite- } \\
\text { rima(\%) }\end{array}$ & $\begin{array}{l}\text { Bervariasi } \\
\text { ada } 60: 40, \\
\text { atau } 70: 30\end{array}$ & $\begin{array}{l}\text { Bervariasi, ada yang } 60: 40 \text {, atau } \\
70: 30 \text {, ada yang berdasarkan } \\
\text { kenaikan bobot badan per } \mathrm{kg} \text {, nilai } \\
\text { nominal tertentu per periode }\end{array}$ & $\begin{array}{l}\text { Bervariasi, ada yang 60:40, } \\
\text { atau } 70: 30 \text {, nilai nominal } \\
\text { tertentu per periode } \\
\text { produksi }\end{array}$ \\
\hline & Cara pembayaran & $\begin{array}{l}\text { Tunai saat } \\
\text { jual }\end{array}$ & Tunai saat jual & Tunai saat jual \\
\hline
\end{tabular}

pemberian pakan, pengendalian kesehatan, dan pengamanan ternak.
pantuk 
Dalam kaitan dengan unsur-unsur kelembagaan, seperti batas jurisdiksi, kewenangan antar pelaku adalah tetap jelas walaupun bagi hasil antara peternak dengan pihak pemodal swasta hanya kesepakatan lisan namun tetap berjalan dengan baik. Berdasarkan kewenangan penggaduh, sistem bagi hasil menunjukkan insentif yang diperoleh kepada penggaduh belum proporsional, bila dikaitkan dengan korbanan yang dikeluarkannya. Pelaksanaan unsur-unsur kelembagaan seperti ini mungkin saja berkaitan erat dengan : (1) profil pasar, sebagai salah satu ciri khas komoditas yang dibagi hasilkan. Maksudnya, dengan kemudahannya untuk dijual (setiap saat bisa terjual) serta memiliki kaitan erat dengan faktor sosial ekonomi budaya masyarakat di wilayah penelitian.

Mencermati fenomena di atas, seirama dengan Pranadji (2004:7) yang menyatakan bahwa secara inklusif profil pasar juga menentukan corak dari bentuk kelembagaan produksi; (2) kondisi sosial ekonomi masyarakat yang rendah sehingga berakibat dengan posisi tawar yang lemah. Hal ini juga berkaitan dengan unsur bounded rationality dari penggaduh sebagai konsekwensi dari kapasitas mereka dalam mengakses sejumlah informasi penting seperti: informasi tentang teknologi, inofrmasi pasar akhir dan bagaimana meramu hal-hal tersebut dalam kerangka kontrak bagi hasil dengan pihak lain; (3) masih sangat terbatas atau tidak ada alternatif usaha ekonomi produktif lainnya.

\section{Dampak Kelembagaan Bagi Hasil Terhadap Kinerja Usaha}

Kinerja sebagai gambaran umum tentang hasil proses dari suatu periode produksi suatu usaha. Gambaran tersebut dapat digunakan sebagai acuan dalam menilai efektivitas atau efisiensi proses produksi, sekaligus dapat diprediksikan keberlanjutan dari usaha tersebut.

Indikator kinerja usaha meliputi : penerimaan, pendapatan (net income), dan keuntungan (net profit), nilai tingkat pengembalian modal (ROI). Pengertian pendapatan (net income), yaitu nilai penerimaan total dikurangi biaya produksi. Batasan dari keuntungan (net profit) yaitu net income dikurangi biaya transaksi selama setahun.

Hasil analisis perbedaan indikator kinerja usaha penggemukan dari penggaduh dan peternak mandiri tertera dalam Tabel 2

Berdasarkan Tabel 2 , hasil uji $F$, maka uji beda rata-rata antar jenis penggaduh menunjukkan perbedaan yang tidak nyata $(P>0,05)$. Namun untuk perbedaan rata-rata antara penggaduh dan peternak mandiri menunjukkan perbedaan yang sangat nyata $(P<0,01)$. Hal ini disebabkan oleh faktor share yang diperoleh penggaduh adalah kecil Hasil yang sama dari uji beda rata-rata nilai dari indikator kinerja lainnya yang meliputi : pendapatan (net income), net profit, dan $R O I$ dari usaha penggemukan. Besaran ROI pada usaha penggemukan dari peternak penggaduh, ini juga menunjukkan bahwa masih belum maksimalnya pemanfaatan aset usaha tani ternak (terutama lahan untuk sumber pakan). Oleh karena itu, peluang peningkatan jumlah ternak yang dikelola/digaduhkan masih tinggi. Dengan kata lain, besaran pendapatan dari peternak mandiri sebenarnya dapat merupakan Opportunity Cost dari penggaduh. 
Tabel 2. Hasil Analisis Ujibeda rata-rata Indikator Kinerja Usaha Penggaduh dan/dengan Peternak Mandiri Tipe Penggemukan

\begin{tabular}{|c|c|c|c|c|c|c|c|}
\hline \multirow[t]{2}{*}{ Indikator } & \multirow[t]{2}{*}{ Kode } & \multirow{2}{*}{$\begin{array}{l}\text { Rata- } \\
\text { rata } \\
\text { (Rp000) }\end{array}$} & \multicolumn{2}{|c|}{ Uji- F } & \multicolumn{2}{|c|}{ Uji Tukey } & \multirow[t]{2}{*}{ Uji t } \\
\hline & & & $\begin{array}{c}\text { Antar } \\
\mathrm{Pi}\end{array}$ & $\begin{array}{l}\text { Antar } \\
\text { Pi \&M }\end{array}$ & Antar Pi & Antar Pi \& M & \\
\hline \multicolumn{8}{|c|}{ Penerimaan } \\
\hline & P1 & $2.376,30$ & t.n & $* *$ & $\begin{array}{l}1 \text { vs } 2 \\
* *\end{array}$ & $1 \mathrm{vs} 2^{\mathrm{tn}}$ & $* *$ \\
\hline & $\mathrm{P} 2$ & $2.299,05$ & & & $\begin{array}{l}1 \text { vs } 3 \\
* *\end{array}$ & 1 vs $3^{\text {tn }}$ & \\
\hline & P3 & $1.944,53$ & & & 2 vs $3^{\text {tn }}$ & 1 vs $4 * *$ & \\
\hline & M & $5.661,86$ & & & & 2 vs $4^{* *}$ & \\
\hline & & & & & & 3 vs $4 * *$ & \\
\hline \multicolumn{8}{|c|}{ Net Income } \\
\hline & P1 & $2.061,35$ & t.n & $* *$ & $\begin{array}{l}1 \text { vs } 2 \\
* *\end{array}$ & $1 \mathrm{vs} 2^{\mathrm{tn}}$ & $* *$ \\
\hline & P2 & $2.035,93$ & & & $\begin{array}{l}1 \text { vs } 3 \\
* *\end{array}$ & 1 vs $3^{\text {tn }}$ & \\
\hline & P3 & $1.759,31$ & & & 2 vs $3^{\text {tn }}$ & 1 vs $4 * *$ & \\
\hline & M & $3.149,22$ & & & & 2 vs $4 * *$ & \\
\hline & & & & & & 3 vs $4 * *$ & \\
\hline \multicolumn{8}{|l|}{ Net Profit } \\
\hline & $\mathrm{P} 1$ & $1.943,15$ & t.n & $* *$ & $\begin{array}{l}1 \text { vs } 2 \\
* *\end{array}$ & $1 \mathrm{vs} 2^{\mathrm{tn}}$ & $* *$ \\
\hline & P2 & $1.919,31$ & & & $\begin{array}{l}1 \text { vs } 3 \\
* *\end{array}$ & 1 vs $3^{\text {tn }}$ & \\
\hline & P3 & $1.650,47$ & & & 2 vs $3^{\text {tn }}$ & 1 vs $4^{* *}$ & \\
\hline & M & $3.124,88$ & & & & 2 vs $4 * *$ & \\
\hline & & & & & & 3 vs $4 * *$ & \\
\hline \multicolumn{8}{|l|}{ ROI } \\
\hline & $\mathrm{P} 1$ & 18,09 & t.n & $* *$ & $\begin{array}{l}1 \text { VS } 2 \\
* *\end{array}$ & $1 \mathrm{vs} 2^{\mathrm{tn}}$ & $* *$ \\
\hline & P2 & 17,34 & & & $\begin{array}{l}1 \text { vs } 3 \\
* *\end{array}$ & 1 vs $3^{\text {tn }}$ & \\
\hline & P3 & 16,69 & & & 2 vs $3^{\text {tn }}$ & 1 vs $4 * *$ & \\
\hline & M & 32,23 & & & & 2 vs $4^{* *}$ & \\
\hline & & & & & & 3 vs $4 * *$ & \\
\hline
\end{tabular}

Keterangan : $\mathrm{P} 1$ =penggaduh dari pemodal pemerintah, $\mathrm{P} 2=$ penggaduh dari pemodal swasta luar, $\mathrm{P} 3=$ penggaduh dari pemodal swasta lokal, $\mathrm{M}=$ Peternak Mandiri. t. $\mathrm{n}=$ berbeda tidak nyata,$* *=$ berbeda sangat nyata 
Dalam pada itu, melihat kinerja produksi seperti pertambahan bobot rata-rata harian ( average daily gain atau $A D G$ ) antara ternak yang dipelihara antar jenis penggaduh dan petenak mandiri (dalam usaha penggemukan) sebenarnya adalah relatif sama seperti yang tertera pada Tabel 3.

Tabel 3. Rata - Rata Pertambahan Bobot Harian Ternak

\begin{tabular}{clr}
\hline No & \multicolumn{1}{c}{ Jenis Peternak } & $A D G(\mathrm{gram})$ \\
\hline 1 & Penggaduh ternak pemerintah & 409,53 \\
2 & Penggaduh ternak Swasta Luar & 378,41 \\
3 & Penggaduh ternak Swasta Lokal & 410,88 \\
4 & Peternak Mandiri & 399,71 \\
\hline
\end{tabular}

Profil pertambahan bobot badan (average daily gain $=\mathrm{ADG}$ ) tersebut di atas yang relatif sama antar usaha penggaduh dan peternak mandiri, kemungkinan besar disebabkan oleh teknologi budidaya yang relatif sama, mulai dari pemilihan bakalan, umur, profil pakan (jenis, jumlah dan mutu) dan penanganan lainnya dalam aspek budidaya. Bila dibandingkan dengan potensi $A D G$ yang dapat diperoleh, maka $A D G$ dalam riset ini dikatakan belum optimal bila dibandingkan dengan seperti yang dilaporkan Siregar (1997:90-91), untuk ternak sapi Bali, potensi $A D G$ ya adalah 660 gram.

Berdasarkan uraian di atas dapat dikatakan bahwa kehadiran kelembagaan bagi hasil belum berdampak nyata terhadap tampilan produksi/produkvitas usaha penggemukan sapi potong. Hasil ini serupa dengan hasil riset (Fujimoto, 1983 : 256) bahwa tidak ada pengaruh status penguasaan lahan sebagai kelembagaan bagi hasil terhadap produktivitas padi. Walaupun berbeda dengan hasil Nono dkk, 2009) dengan indikator kinerja usaha pertanian pada daerah irigasi yang meliputi : total penerimaan, pendapatan (net income), keuntungan (net profit), $\mathrm{R} / \mathrm{C}$, dan tingkat pengembalian modal (return on invesment/ROI). Dalam hal ini kinerja usaha penggadai dan penyewa lebih baik daripada kinerja pemilik dan penggarap.

Berdasarkan fakta tersebut di atas, tidak berarti bahwa kelembagaan bagi hasil tidak diperlukan dalam pengembangan usaha. Dikatakan demikian karena peternak umumnya memilki sejumlah keterbatasan vital yang meliputi : modal, akses terhadap ipteks atau pasar (input dan output). Jadi, kehadiran kelembagaan bagi hasil memberikan kesempatan bagi penggaduh untuk dapat mengoptimalkan sumber daya yang dimilikinya sehingga memperoleh tambahan pendapatan. Ditegaskan oleh Nono dkk., 2010 bahwa kinerja usaha pertanian (aneka tanaman pangan, peternakan dan perkebunan) sangat ditentukan oleh kapasitas lembaga dan kelembagaan yang terbentuk selain faktor lainnya.

Untuk menggambarkan seberapa besar efisiensi yang dilakukan peternak secara otonom diukur dari nisbah antara penerimaan dan biaya produksi (tunai dan tidak tunai ). Efisiensi usaha menunjukkan seberapa hemat penggunaan sumber daya (atau faktor produksi) dalam suatu proses produksi akan menentukan keberlanjutan suatu usaha. Berdasarkan Soekartawi (1995: 57) salah 
satu ukuran efisiensi suatu usaha adalah nilai nisbah antara total penerimaan (tunai atau tidak tunai) dengan total biaya (tunai dan tidak tunai) dari suatu proses produksi dalam suatu periode waktu tertentu atau $\mathrm{R} / \mathrm{C}$ ratio. Dengan kata lain, besaran nilai $\mathrm{R} / \mathrm{C}$ menggambarkan seberapa hemat proses produksi yang dilakukan peternak mandiri (tertera pada Tabel 4).

Tabel 4. Efsiensi Usaha Sapi Potong (R/C) Peternak Mandiri

\begin{tabular}{|c|c|}
\hline Uraian & Nilai \\
\hline$R / C$ & 1,87 \\
\hline $\mathrm{R} / \mathrm{C}(\mathrm{TK})$ & 0,70 \\
\hline $\mathrm{R} / \mathrm{C}$ (pakan) & 0,17 \\
\hline Rata-rata pemilikan (ekor) & 2,11 \\
\hline $\mathrm{n}$ & 35 \\
\hline
\end{tabular}

Berdasarkan Tabel 4, nilai R/C cukup tinggi (karena belum memperhitungkan nilai korbanan dari tenaga kerja keluarga). Namun setelah diperhitungkan dengan nilai upah tenaga kerja (setara upah buruh tani harian) dan nilai pakan, maka nilai R/C sangat kecil atau merugi. Jadi, pada pola usaha ternak sapi potong seperti saat ini yang dicirikan oleh: (a) mengandalkan input lokal (tenaga kerja berasal dari anggota keluaga sendiri, pakan berasal dari kebun sendiri atau lahan komunal termasuk dari kawasan hutan); (b) organisasi usaha berbasis rumah tangga (keluarga), dapat dikatakan masih menguntungkan pada kisaran pemlikan sebanyak $1 \mathrm{~s} / \mathrm{d} 4$ ekor.

\section{Implikasi Pengembangan}

Berdasarkan gambaran di atas, maka model yang disarankan, khusus untuk program (atau bagi hasil) dengan pemodal pemerintah, hendaknya pada tahap persiapan seperti pembelian bakalan sebaiknya langsung ditangani peternak pengggaduh (sebagai anggota kelompok atau lembaga tertentu). Tujuannya untuk meminimalisir sejumlah free rider pada tahap tersebut. Jadi hendaknya dilengkapi dengan syarat kecukupan adalah penggaduh wajib bergabung dalam lembaga tertentu antara lain Koperasi. Lembaga tersebut diharapkan dapat dijadikan basis untuk : (1) meningkatkan kapasitas pengelolaan usaha penggaduh sehingga memiliki peluang/potensi bargaining yang lebih baik dalam berhubungan dengan pasar (input dan output); dan (2) akses terhadap permodalan dan teknologi. Dengan kata lain, kehadiran lembaga tersebut berpeluang besar berdampak kepada peningkatan produktivitas, peningkatan keadilan share, dan kecepatan/ketepatan merespon pasar (atau dapat mengontrol pasar) serta menurunkan biaya transaksi.

Untuk potensi pemanfaatan sumber daya lahan kawasan kehutanan diperlukan ketegasan dari pemerintah untuk pembangunan kehutanan berbasis masyarakat (PHBM) sekitar hutan yaitu masyarakat petani peternak. Oleh karena itu, idealnya PHBM difokuskan kepada pembangunan hutan berbasis ternak. Maksudnya, hutan dapat sebagai bank atau pabrik pakan. 


\section{KESIMPULAN DAN SARAN}

\section{Kesimpulan}

a. Berdasarkan indikator kinerja usaha yang meliputi: penerimaan, pendapatan, keuntungan dan tingkat pengembalian modal dapat dinyatakan bahwa kinerja usaha peternak mandiri lebih baik daripada kinerja usaha penggaduh

b. Kelembagaan bagi hasil belum meningkatkan produktivitas usaha.

c. Keberadaan sistem bagi hasil memberikan peluang bagi penggaduh dan keluarganya untuk optimalisasi sumber daya (lahan dan tenaga kerja) sehingga meningkatkan potensi pendapatannya.

\section{Saran -saran :}

Dalam kaitan dengan pengembangan sapi potong yang disarankan untuk :

1. Pemerintah, dalam hal ini amat diperlukan instrumen kebijakan untuk: (a). peningkatan penyediaan/ penggunaan pakan terutama pada musim kemarau melalui pemanfaatan lahan potensial seperti kawasan hutan dan (b). Modifikasi sistem bagi hasil termasuk aturan/skim modal dengan peternak

2. Pemodal, dapat melalui: (a). Pemantapan terhadap sistem bagi hasil terutama penataan teknologi budidaya (seperti pakan, dan pengendalian kesehatan) dan (b) Membantu mengorganisir peternak sehingga mampu meningkatkan efisiensi kelembagaan bagi hasil

3. Peternak. Dalam rangka meningkatkan produktivitas/efisiensi usaha dapat melalui : (a) adopsi teknologi pakan tepat guna untuk meningkatkan ketersediaan pakan sepanjang tahun, (b) Untuk meningkatkan posisi tawarnya hendaknya berada dalam lembaga tertentu seperti koperasi.

\section{DAFTAR PUSTAKA}

Fujimoto, A, 1983. Income Sharing among Malay Peasants : A Study of Land Tenure and Rice Production. Singapore University Press. Singapore .

Hayami, Y., and V. W Ruttan. 1984. Agricultural Development. The Johns Hopkins Univesity Press. Baltimore and London.

Nono, Obed H., Yunus, M., Adutae, S.A. 2009. Analisis Status Penguasaan lahan dan Kinerja Usaha Pertanian Pada daerah irigasi di Kabupaten Sumba Timur. Penelitian Kerjasama Lemlit Universitas Nusa Cendana dengan Pemda Sumba Timur -NTT.

Adutae, S.A. 2010. Analisis Kinerja Sektor Pertanian di Kabupaten Sumba Timur. Penelitian Kerjasama Lemlit Universitas Nusa Cendana dengan Pemda Sumba Timur -NTT. 
Pakpahan, A. 1989. Kerangka Analitik Untuk Penelitian Rekayasa Sosial : Perspektif Ekonomi Institusi. Dalam Prosiding Patanas Evolusi Kelembagaan Pedesaan. Ditengah Perkembangan Teknologi Pertanian. Pusat Penelitian Agroekonomi. Badan Penelitian dan Pengembangan Pertanian. Bogor.

Pranadji, T. 2004. Diagnosa Kerapuhan Kelembagaan Perekonomian Pedesaan. Dalam Forum Agro Ekonomika FAE, Volume 21, No.2 Desember 2003. P3SE Pertanian Balitbangtan. Deptan. Jakarta

Rasyid, H. 1994. Teknik Penarikan Sampel dan Penyusunan Skala. Penyunting Kismantoroadji. Program Pasacasarjana Unpad. Bandung.

Siagian, D., dan Sugiarto. 2002. Metoda Statistika untuk Bisnis dan Ekonomi. Edisi Ke-2. PT. Gramedia Pusaka Utama Jakarta

Soekartawi. 1995. Analisis Usahatani. Penerbit Universitas Indoensia -UI Press. Jakarta 